\title{
Sustainable Livelihood Strategies: How Urban Community Resilient Towards Disaster?
}

\author{
Navila Ulfi Fauziyanti and Dyah Rahmawati Hizbaron \\ ${ }^{1}$ Department of Environmental Geography, Faculty of Geography, Universitas Gadjah Mada, Yogyakarta, Indonesia \\ ${ }^{2}$ Faculty of Geography, Universitas Gadjah Mada, Yogyakarta, Indonesia
}

Received: $2019-11-23$ Accepted: 2020-05-05

Keywords:
livelihood; sustainable; disaster; resilient; urban; Indonesia

Correspondent email: dyah.hizbaron@ugm.ac.id

\begin{abstract}
It has been more than a decade after 5.9 SR earthquakes hit one of the most destructed area Tembi Hamlet, Bantul District, Yogyakarta Province. Amidst the wreaking havoc, the area gained its resilient in no time. This research, aimed to 1) explore what are the factors influential towards local resilient, especially micro-small-medium enterprises; and 2) analyze strategies to tackle disaster. It employed mix method, while the key questions were developed using "Sustainable Livelihood Approach" by DFID, geared with "Pentagram Asset" mapping for each spatial and temporal unit. The research impetus is to explore urban resilient of Tembi, Bantul using three important variables such as access, asset and activities. The research sample was taken through purposive sampling for Small-Medium Scale Enterprises in the research area. The data collection employed questionnaires and in-depth interviews and observed through ancillary data. There are 3 important variables measured within the research, such as access, asset and activity of SMSE. Hereafter, the research classified the observed data into scales, which later on expanded into the pentagram scale. The model to formulate research findings developed using "Sustainable Livelihood Approach" by DFID. The data processing technique used software SPSS, Microsoft Excel and ArcGIS were geared with "Pentagram Asset" mapping for each spatial and temporal unit. The result revealed that 1) the micro-small-medium enterprises in urban area are resilient towards earthquake due to fair physical, natural and financial assets management and abundant social, human and political assets. These assets have created enabling environment towards behavioral change of urban society; 2) Despite various livelihood strategies existed in urban areas, the research highlighted three types of livelihood strategies within disaster risk management perspective, i.e. survival (disaster), consolidation by no-change plan mechanism and accumulation strategies by change plan mechanism (post disaster). Critically, pentagram assessment is able to identify feasible local assets and activities, however it left the policy, institution, interaction and multi sector aspects from the spotlight. Herewith, the research proposes evaluation scan to rethinking sustainable livelihood approach within disaster risk management by adding these aspects into the observation. It also revealed that local autonomous initiatives to extend urban based economic activities and supported by abundant political interest play pivotal role in disaster management at developing countries.
\end{abstract}

\section{Introduction}

Among various natural hazards induced-disaster hits Indonesia, earthquake had caused severe damage to the environment. As one of among many natural disasters, earthquake is a geomorphic process, described by sudden slip towards fault, volcanic or magmatic activity then resulted ground shaking as well as radiated seismic energy that included other sudden shock changes at the earth surface (UNISDR, 2004). For developing countries, these disasters have constituted a heavy drag on development (Nakagawa and Shaw, 2004). One major disaster can be a setback to healthy economic growth for years. Hitherto, there is an urgent need of securing community's livelihood from natural disaster by defining short-term and long-term alternatives strategies of sustainable livelihood (Rijanta, et al., 2014). Donations from governments (national, provincial, city or local), NGOs (both international and local), and all of assets left over from post disaster put tremendous efforts into reducing vulnerability and enhancing sustainability in the reconstruction and rehabilitation programs (Shaw, Gupta \& Sharma, 2003). This research tries to highlight the idea on how sustainable the resilience at the research area. Empiric findings indicates that the area was highly supported by the micro-small-medium enterprises, hence this research try to explore how things has been evolving so far.

This research highlights on Tembi Hamlet, Bantul District, Yogyakarta Special Province, Indonesia. Bantul District is an urbanized area at the vicinity of Yogyakarta City, serves as agricultural backbone for the region with strong characteristics of small to medium scale economy on art, tourism and cultural activities. The $6.2 \mathrm{Mw}$ earthquake ever hit the area at May, 27 $7^{\text {th }}, 2006$ caused 5700 death toll and 3.1 billion US\$ economic losses (Kusumasari, Alam, \& Siddiqui, 2010; Hizbaron et al., 2012). Fortunately, this area able to bounce back a year after.

To start with, this research conducts literature study which delimits observation into these following key words, 
such as sustainable livelihood framework, vulnerability and resilience, sustainable livelihood approach within disaster management, temporal aspects within sustainable livelihood and pentagram asset.

There is various understanding towards sustainable livelihood approach. A livelihood itself referred to capabilities, assets, access and activities supported means of living (Scoones, 1997; Scoones, 2009). Chambers and Conway (1991) explained that a livelihood is a peoplecentered study, which appointed existence of people, either individuals or households, their capabilities as well as their tangible assets (i.e. natural, human and physical) and intangible assets (social, political, claims, access and or relationship) as a mean of living (Chambers \& Conway, 1991; Farrington, Ramasut, \& Walker, 2002; Carney, 2003). Initially, sustainable livelihood approach appeared within scientific discussion since late 1990s (Carney, 2003; Plummer \& Armitage, 2007; Scoones, 2009). The main goal observing sustainable livelihood is to propose suitable livelihood for poverty eradication (Rijanta et al., 2014).

Rooted from social science, this framework argued upon the importance of livelihood strategies mostly at rural areas, whereas more diverse livelihood at rural areas potentially minimized poverty, normatively. However, it is not an afternight result to diversify livelihood at rural area, it requires long process with very intensive community involvement and government assistance. Theoretically, sustainable livelihood approach was mainly poverty-driven-strategies to catch up with development (Baiquni, 2007; Rijanta et al., 2014). It has developed intentionally using some of these principles, i.e. people centered, responsive, participative, multi-level, partnership, differentiated, sustainable and dynamic (Carney, 2003; Farrington, Ramasut, \& Walker, 2002). Furthermore, sustainable livelihood approaches are assets identification, vulnerability level, policy and institution, also interaction among these key words (Carney, 2003).

The classic concept developed earlier from DFID, highlighted that as the manpower changes local assets, hence, sustainable livelihood is not merely taken assets as main aspect. However, it also put access and activities as other aspects to be evaluated. There are five important assets, i.e. human, physical, financial, natural and social (DFID, 1999). Amidst existing vulnerability context (shocks, stress, seasonality and trends), if a condition able to pose adequate assets that forms stable social political structure and process, and enable people to gain more income, increase well-being, reduce vulnerability and improve security as well as sustainability, thus, it is entitled as sustainable livelihood (Figure. 1).

Disaster discourse has given wide variety of important key words, such as hazard, vulnerability, capacity, risk and resilience. Traditionally, hazard-risk framework perpetuates uneven spatial distribution towards natural energy which possible to cause certain degree of magnitude, frequency, intensity and impacts to human (UNDP, 2004). Meanwhile, both resilience and vulnerability are concepts that have evolved in different disciplines and applied in different fields of practice-disaster risk management being one of these fields (Fekete, Hufschmidt \& Kruse, 2014). Hazard and risk generally most discussed compared to vulnerability. In natural science for example, hazard and risk are two important term to evaluate potential threat and potential losses, put vulnerability at the shadow of both terms (Cardona, 2003; Pelling, 2003, Birkman, 2006; Thywissen, 2006, Hizbaron et al., 2018). As for social science, hazard and risk are understood as compelling factors not necessarily due to natural event per se, it could also embraces other unfortunate events such as lack of socioeconomic, and political access which impairs human vulnerability (Birkmann, 2006; Hizbaron, Baiquini, Sartohadi, \& Rijanta, 2012). Hereafter, the vulnerability broadly defined as the conditions determined by physical, social, economic and environmental factors or processes which increase the susceptibility of an individual, a community, assets or systems to the impacts of hazards (UN/ISDR, 2004). Vulnerable group generally includes those whose assets are insecure and or those whose livelihood is not sustainable to adapt, cope or resist from disaster occurrence (Hizbaron et al., 2012; ibid, 2015, ibid, 2016). The resilience generally defined as the ability of a system, community or society exposed to events to resist, absorb, accommodate, adapt to, transform and recover from the effects of a hazard in a timely and efficient manner, including through the preservation and restoration of its essential basic structures and functions through risk management (UN/ISDR, 2004).

Lack of economic opportunities, limited access to politics as well as marginalized social groups deemed as main stress and shock cause unsustainable livelihood. Derived from spatial perspective, hazard, vulnerability and risk information are dynamics and unique (Hizbaron et al., 2012; ibid, 2016). This research proposes this following idea to rethinking sustainable livelihood approach in the context of disaster risk management (Figure. 2).

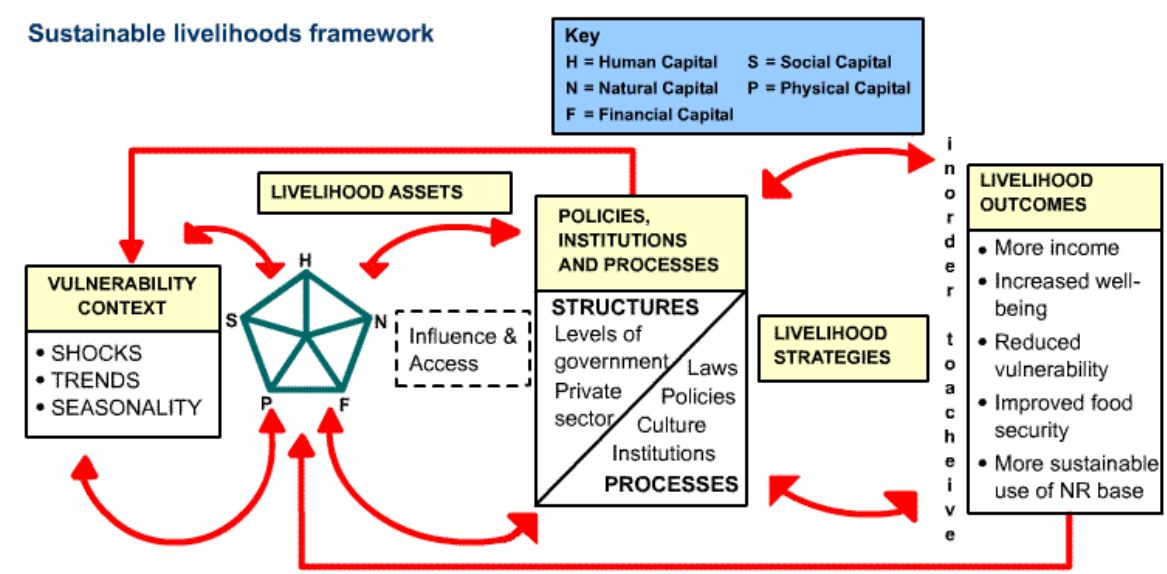

Figure 1. Sustainable Livelihood Framework (DFID, 1999) 


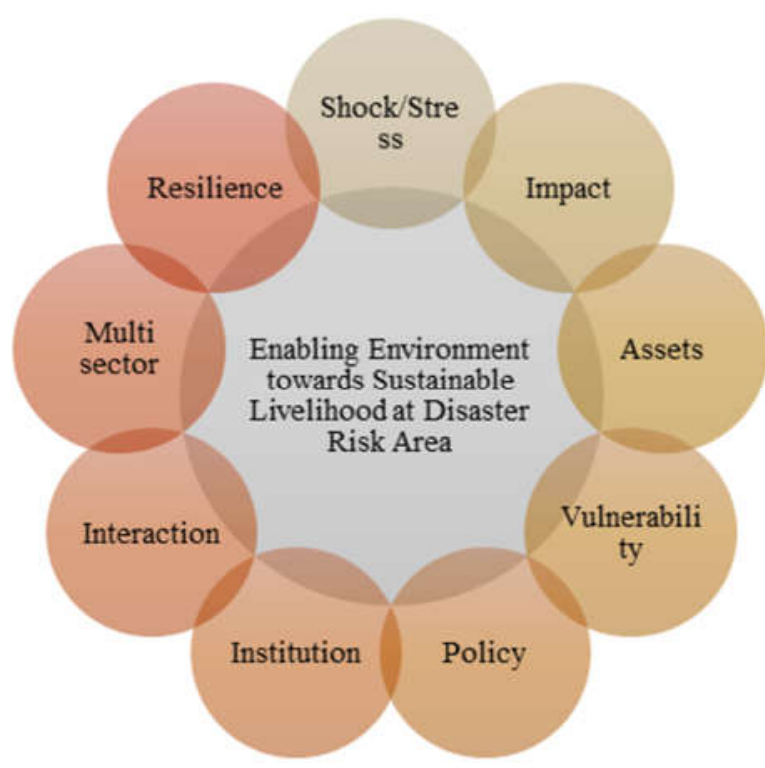

Figure 2. Re-thinking concept of sustainability livelihood approach in the context of disaster risk management (Analyze Result, 2016)

Sustainable livelihood attached within spatial and temporal context. There are social, economic and politic processes that run indifferently in each spatial unit. Hypothetically, such unique livelihood assets and specified social, economic and politic process tag along with existing natural assets available within the spatial unit. Urban poor characterized by socially segregated group, supported by economically complex sectors, unlike in rural area, whereas single livelihood (agriculture) became central to the discussion. To add, urban poor generally politically excluded, and resided at environmentally polluted area, with very limited access to urban facilities. However, urban problem are generous, not merely focused upon urban poor. In developing countries, urban areas also experiences rapid urbanization process, as the area exposed to rapid physical development, whilst urban dwellers experienced very simple yet humble lifestyle as rural characteristics (Farrington, Ramasut, \& Walker, 2002).

Sustainability refers to locality ability to overcome damage i.e. economic losses, diminished productivity, or reduction of quality of life (Milleti, 1999). Three main reasons for sustainable, such as it can cope with, it can recover from any stresses and shocks, also it can maintain to enhance its capabilities and assets without undermines their future natural assets (Chambers \& Conway, 1991; Scoones, 2009). In the disaster risk management cycle there are three main phases, pre disaster, per disaster and post disaster. In here, sustainable livelihood approach applied as an alternative solution to escape from hazard in form of stress (a small but regular, quite predictable, with accumulated impact such as poverty) and also shock (a large, yet infrequent, unpredictable, and causing immediate impacts such as disaster). Analytically, the identified impacts are often includes assets which increase people's vulnerability towards disaster (Cutter, et al., 2008; Cutter, Burton, \& Emrich, 2010).

Conceptually, there are several conditions at the aftermath of disaster occurrence. These conditions are collapse condition, stable condition and regenerate condition or built back better from normal condition (Baiquni, 2007; Hizbaron, et al., 2014). Stable and regenerate conditions are often entitled as resilient condition. Herewith, the research tries to frame the sustainable livelihood in the context of disaster risk reduction framework (Figure. 3).

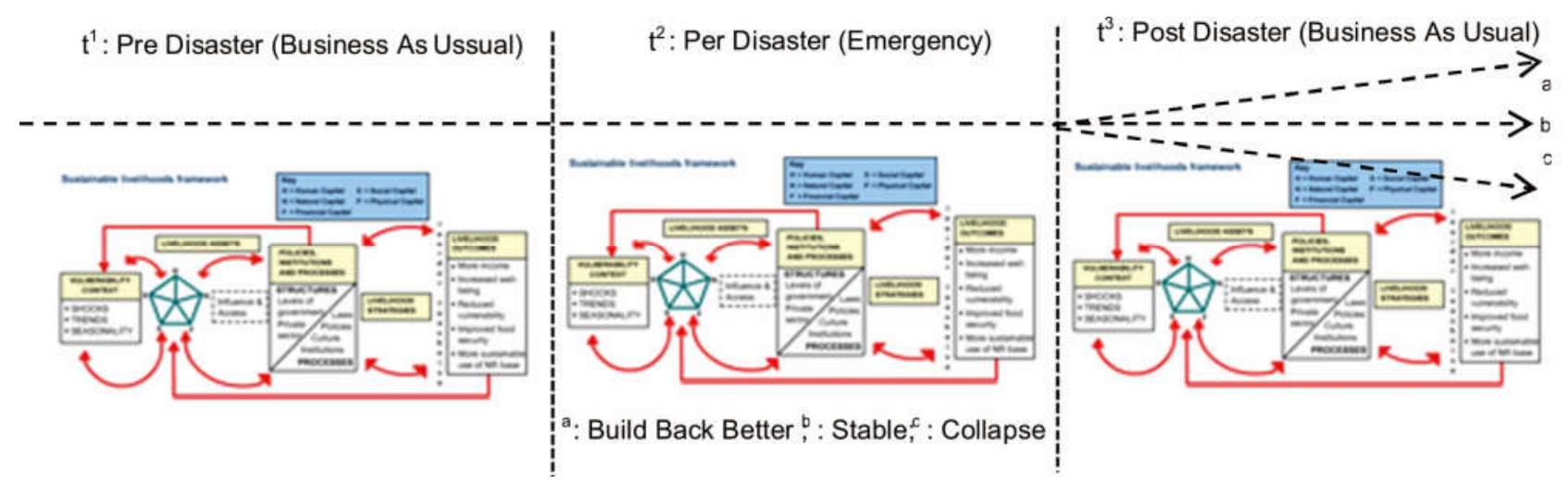

Figure 3. Temporal Framework for Sustainable Livelihood Approach in Disaster Risk Management (DFID, 1999 and Analyze Result, 2016) 


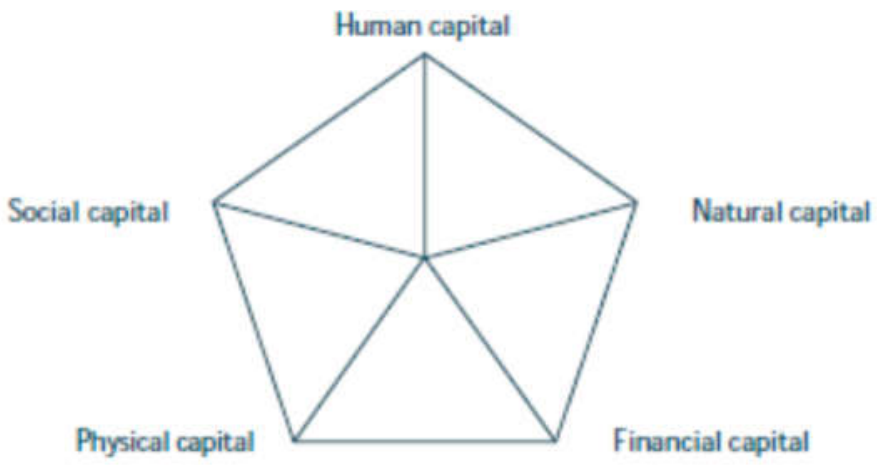

Figure 4. Pentagram Asset (DFID, 2001)

The local resilient adhere to five different assets, presented in pentagram. Quantitatively, the pentagram is possible to measure existing assets from two different time periods. The five related livelihood assets can be represented through pentagon assessment or pentagram asset that can be seen in Figure.4. Pentagram asset is part of the concept of sustainable livelihood that is used as the basis for the formulation of a sustainable livelihood structure (DFID, 2001). The shape variation of the pentagon structure of this asset will depend on the level of ownership and access to access and is able to give an idea of the level of well-being (Ellis, 2000).

Accordingly, White (1991) in Baiquni (2007) classified three essential livelihood strategies, such as: survival, consolidation and accumulation. Survival strategy refers to any means to earn basic living from local natural resource, or accepting any occupation (which require no specific skills) that exist at the area. Consolidation strategy aims at securing and stabilizing basic living and improving to secondary need or even tertiary need collectively. Meanwhile, accumulation strategy refers to any dynamic effort to use local natural resource, to secure and to stabilize basic living, to improve local earning for saving or further investment and to expand their local value for more market bases.

This research, aimed to 1) explore what are the factors influential towards local resilient, especially micro-small- medium enterprises; and 2) analyze strategies to tackle disaster. It employed mix method, while the key questions were developed using "Sustainable Livelihood Approach" by DFID, geared with "Pentagram Asset" mapping for each spatial and temporal unit.

\section{THE METHODS}

\section{Location of Study Area}

Tembi Hamlet is administratively located at Sewon Sub District - Bantul District, Yogyakarta Province-Java Island, Indonesia and about 8,5 kilometers from center of Yogyakarta City. Historically, Yogyakarta Province in general exposed to seismic activity above 5 Richter Scales at 1867, 1943, 1981, 2001 and the latest was 2006. This study area proximately situated less than $10 \mathrm{~km}$ to the north of the strongest active fault in Bantul District, which were predicted as the main source of seismic activity.

Bantul District is home to nearly 823.400 inhabitants by 2004. The demographic Figure at Bantul District has grown to 945.564 inhabitants by 2010 and projected to increase up to 955.015 inhabitants in 2014 - 2020, with total area of $508 \mathrm{~km}^{2}$ (BPS Bantul, 2016; Disdukcapil Bantul, 2010). Specifically, Tembi Hamlet occupied by nearly 943 inhabitants by 2015, with 462 male and 481 female that makes gender ration quite balance. According to Bantul District Government Regulation No. 4 Year 2011 on Spatial Plan of Bantul District, Tembi area designated as strategic area for environmental protection. The land use included residential buildings, art galleries, also workshop production, active agriculture land, paddy fields and other micro-small-medium enterprises activities. The research area is predominantly for settlement and productive agriculture activity, whilst its location is adjacent towards active faults line. Specifically, Tembi Hamlet was impacted nearly $80 \%$ out of its total areas, which included residential buildings, art galleries, also workshop production and many more (Theo, 2016). The Figure. 5 indicated that most of the current land use in Tembi area predominantly function not merely as settlements, but also as tourism destination and tourism facilities, such as homestay, batik galleries, and craftwork workshop.

Meanwhile in Bantul District, there was nearly $73 \%$ - 81.5\%
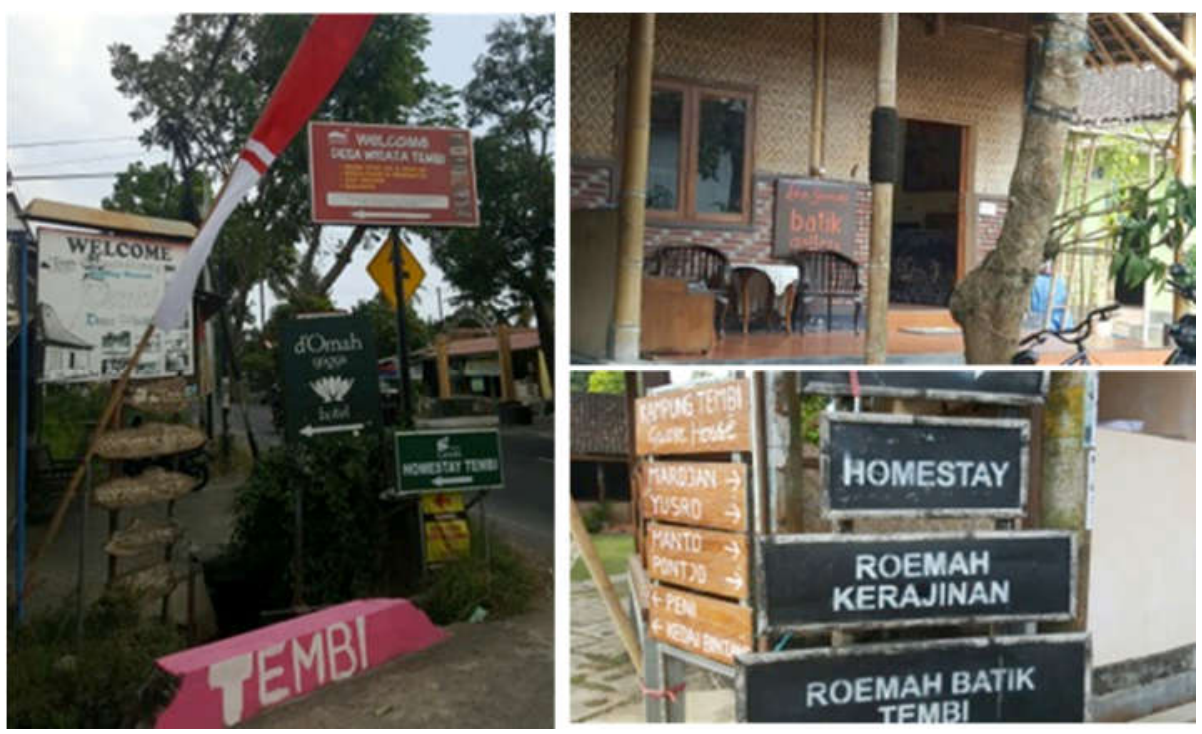

Figure 5. Tembi, the research area predominantly occupied as tourism areas, with main attraction as centre for Javanesse art and culture, provided with local settlements as homestay, art galleries and craftwork workshop. (Primary Data, 2016) 
out of its built environment were ruined. Statistically, $88 \%$ out of total death toll and $61 \%$ out of total injured accumulated in Bantul District (Ministry of Public Works, $2006)^{1}$. In terms of its economic impact, the area suffered from 23\% GDP decline (Hadi, 2008). Despite its destruction, the area had gained its resilient in no time, due to external and internal factors existed in the area. Provincial Decree dated $31^{\text {st }}$ August 2007, signed by Royal Highness of Sultan Yogyakarta as the Governor of Yogyakarta Province stated that this hamlet was one among several other hamlets able to revive from the last earthquake occurrence less than a year. The following figure 6 presents research flowchart.

Local business in Tembi referred to MSME (Micro-SmallMedium Enterprise). There are at least 84 micro-smallmedium enterprises existed in Tembi Hamlet. The research observes several micro-small-medium enterprises in the research areas, i.e. art/craft gallery owners, shopkeepers, homestay owners, and other business owners. Generally, the MSME are privately owned and operated, which have small number of employees (1 until 10 employees) with assets maximum IDR 50 million and revenues maximum 300 million (Indonesian Government Law No. 20 of 2008 on Micro, Small and Medium Enterprise). The finding towards first objective will be fundamental hypothesis to argue mechanism and process gear up to form sustainable livelihood strategies confronting post-earthquake impact in developing countries. The research conduct interview to $84 \mathrm{MSME}$, and validate research from in depth interview with local government officials, community leaders, local group (Pokdarwis).

\section{Method of Data Collection}

Due to limitation of time reference, the research selected pre disaster, per period and post disaster period to be compared. Unfortunately, the shortcoming are as follow: 1) the respondents have difficulties to recall condition before disaster occurrence since it represent a quite long period of time, however, 2) there are several variables took from previous condition as before the disaster occurrence such as availability of government incentives and donors support to recover from their current state (Table 1).

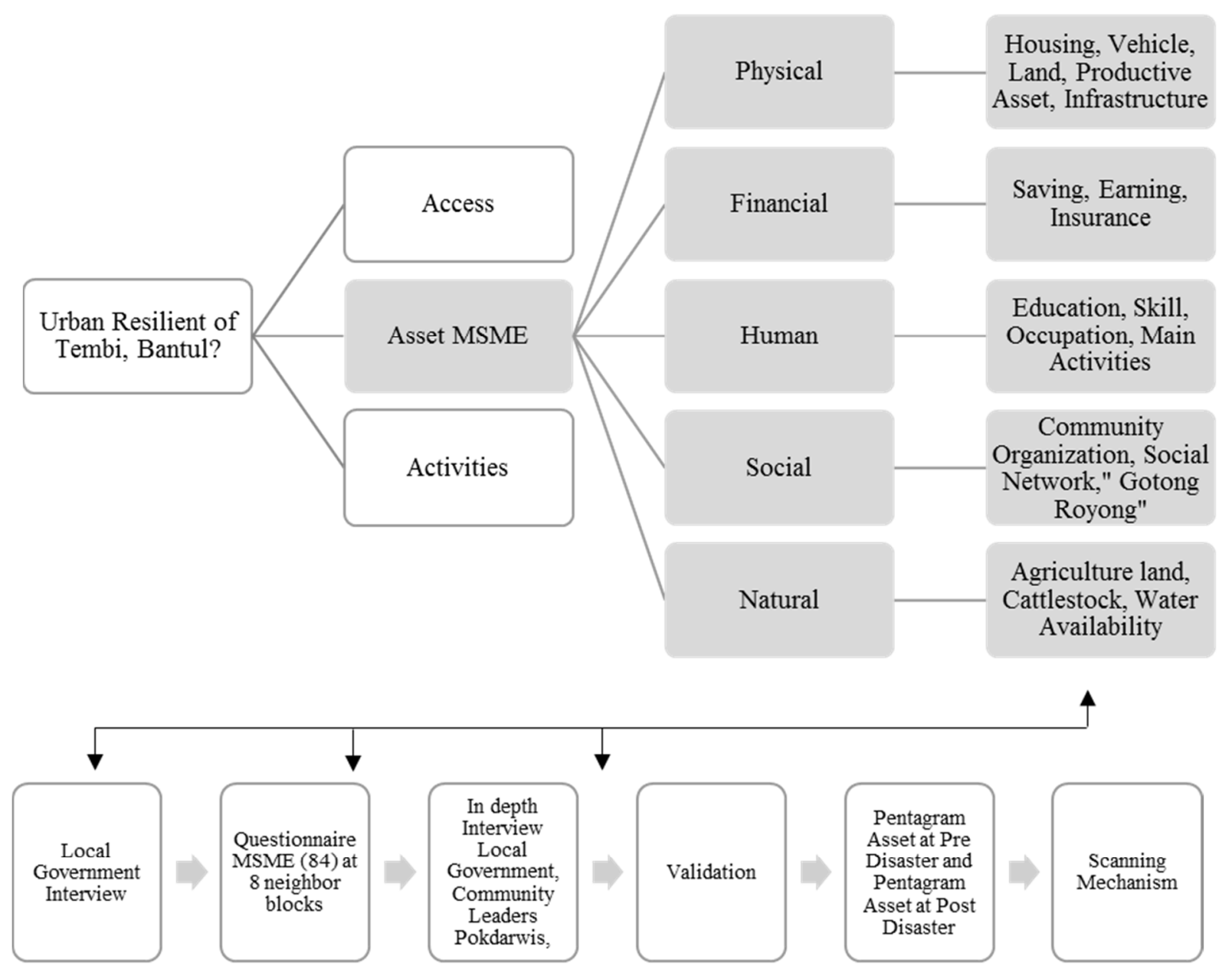

Figure 6. Research flowchart 
Table 1. Research Variables and Indicators

\begin{tabular}{lll}
\hline Timeframe & Variable & \\
\hline \multirow{3}{*}{ Pre-Disaster } & Physical & Housing, Vehicle, Land, Productive Asset, Infrastructure \\
& Financial & Saving, Earning, Insurance \\
& Social & Community organization, Social Network, "Gotong Royong” \\
& Natural & Agriculture Land, Cattlestock, Water Availability \\
& Physical & Housing, Vehicle, Land, Productive Asset, Infrastructure \\
& Financial & Saving, Earning, Insurance \\
& Human & Education, Skill, Occupation, Main Activities \\
& Social & Community organization, Social Network, "Gotong Royong” \\
& Natural & Agriculture Land, Cattlestock, Water Availability \\
& Physical & Housing, Vehicle, Land, Productive Asset, Infrastructure \\
& Financial & Saving, Earning, Insurance \\
& Human & Education, Skill, Occupation, Main Activities \\
& Social & Community organization, Social Network, "Gotong Royong” \\
& Natural & Agriculture Land, Cattlestock, Water Availability
\end{tabular}

Sources: DFID (2001); Baiquni (2007)

Table 2. Reliability Test

\begin{tabular}{lrrrc}
\hline \multicolumn{5}{c}{ Post Disaster Questionnaire Test } \\
\hline \multicolumn{1}{c}{ Asset } & $\mathrm{R}$ & Rtable 1\% & Rtable 5\% & Test Descision \\
\hline Human & 0,372 & 0,220 & 0,286 & Reliable \\
Physical & 0,398 & 0,220 & 0,286 & Reliable \\
Financial & 0,628 & 0,220 & 0,286 & Reliable \\
Natural & 0,708 & 0,220 & 0,286 & Reliable \\
Social & 0,664 & 0,220 & 0,286 & Reliable \\
\hline
\end{tabular}

Sources: Primary Data (2016)

\section{Data Analysis Technique}

The research question designed in Likert scale. Likert scale is one way of determining the scores on each livelihood asset. Although, resilient is not a matter of asset per se, this research highlights asset management during crisis and its afterwards in order to get an underlying factor supporting their resilient. Likert scale in this method used form numerical and semantic. Respondents asked to rate an object or concept on a scale that has two opposite adjectives that will be bipolar scale, which contains two elements of evaluation, the element of potential and activity. Some of the key questions had been tested to some portion of the sample. The following Table 2 indicated the result of reliability and validity test towards the questionnaire. The sampling questionnaire was taken from post disaster.

The research undergone validity test towards 15 indicators withdrawed from 84 respondent, using Pearson Product Moment. It calculates item questionaires scores with the total score of all items questionnaires. It generates valid result if $\mathrm{Rxy}>\mathrm{R}$ table product moment, whilst it generates invalid result if $\mathrm{Rxy}<\mathrm{R}$ table product moment .

\section{RESULT AND DISCUSSION}

At the aftermath of the disaster occurrence, the local livelihood in the research area experienced dynamic change. The last disaster occurrence ruined nearly 30.000 micro-smallmedium enterprises, which induced 29.1 Trillion IDR or 3.314 billion US\$ losses, and indirectly increased unemployment rate from $7 \%$ to $11 \%$ in Bantul District, Yogyakarta and Central Java (UNDP, 2004; Hadi, 2008). Pertaining to the preliminary observation towards 84 respondents randomly selected to represent micro-small-medium enterprises group in the research area, $91.67 \%$ of the total respondent claimed to experience the same occupation or job after disaster event, while the rest of $8.33 \%$ of the total respondent have to change the occupation to maintain their livelihood (Table 3). Among those $91.67 \%$ of the total respondent who did not need to change their occupation claimed that they inquired to adapt 
with post disaster situation by taking side-occupation. The side occupation generally in line to the local change with growing tourism and services. Hereafter, the research argues that, Tembi get access to side job preference, and availability of external capacity to support local resilience.

According to the previous data collection towards disaster impact (2006 earthquake impact), the housing sectors suffered most among other sectors together with social facilities, industry and productive sectors. The disaster impact tremendously affected 2,838 million USD private ownership and left another 297 million USD public ownership at loss (Table 4). In many cases main activities of local dweller was to retrofit/reconstruct their house, workshop and many structures which support their livelihood. Local government program provided incentives IDR 15.000.000 per land unit for reconstruction. This amount of supports organized firmly by local leaders. Normally, they were able to buy construction material to support the reconstruction process using this amount, while local human resource voluntarily supported the reconstruction. Therefore, this research argued that local access to external support were abundant during main activities at the aftermath of disaster occurrence. Again, until recently mechanism to involve local human resource continued. Many of the micro-small-medium enterprises hired neighbors as employee. Although, many scholars argued minimum human resource at urban areas during crisis, this was not the case at Tembi.

Herewith, the research tries to embrace spatial-temporal analysis towards the case of Tembi. There are 8 neighboring blocks within Tembi Hamlet (Figure 7). Among 8 pentagrams, which reflected human, physical, financial, natural and social assets owned by respondent, each neighboring block indicated very unique pentagram patterns.

Each pentagram consists of two connecting lines, which represents asset distribution during emergency situation and aftermath of earthquake. The idea is the more assets through times, the more it supports livelihood in many ways (Baiquni, 2007). However, there is variety in assets ownership in each area (Ellis, 1999). Derived from Figure 9, the social assets (intangible assets) had been tremendous assets to the area; meanwhile natural assets (tangible assets) had claimed limited

Table 3 Respondents livelihood at Tembi, 2017

\begin{tabular}{lcc}
\hline Livelihood Identification & Respondent & Percentage (\%) \\
\hline Individual working with the same occupation & 77 & 91,67 \\
Individual working with different occupation & 7 & 8,33 \\
Total & 84 & 100,00 \\
\hline
\end{tabular}

Source: Primary Data, 2016

Table 4. Disaster impact in research area due to earthquake 2006

\begin{tabular}{lrrrrr}
\hline \multirow{2}{*}{ Sectors } & \multicolumn{2}{c}{ Disaster Impact (USSD) } & \multicolumn{2}{c}{ Ownership } \\
\cline { 2 - 6 } & Damage & Losses & Total & Private & Public \\
\hline Housing & 1,50 & 0,15 & 1,64 & 1,64 & 0,00 \\
Infrastructure & 42,68 & 16,56 & 59,24 & 8,17 & 51,18 \\
Transportation Communication & 9,68 & 0,00 & 9,68 & 0,00 & 9,68 \\
Energy & 24,19 & 16,13 & 40,32 & 0,00 & 40,32 \\
Social Facilities & 0,42 & 8,28 & 9,25 & 0,23 & 0,20 \\
Education Facilities & 180,94 & 6,02 & 0,43 & 62,79 & 124,07 \\
Health and Social Protection & 168,69 & 2,26 & 170,94 & 110,74 & 60,21 \\
Cultural and Religious Facilities & 69,35 & 0,00 & 69,35 & 53,54 & 16,77 \\
Productive Sector & 0,47 & 0,50 & 0,97 & 0,95 & 18,28 \\
Agriculture Sector & 7,10 & 68,81 & 75,80 & 75,26 & 0,65 \\
Business Sector & 19,78 & 12,90 & 32,58 & 14,84 & 17,74 \\
Industry Sector & 0,44 & 419,19 & 0,86 & 856,01 & 0,00 \\
Tourism Sector 8 & 3,87 & 1,94 & 5,81 & 5,81 & 0,00 \\
Cross-Sectoral & 19,89 & 11,83 & 31,72 & 5,16 & 26,56 \\
Government & 14,73 & 0,00 & 14,73 & 0,00 & 14,73 \\
Finance and bank & 5,16 & 0,00 & 5,16 & 5,16 & 0,00 \\
Environment & 0,00 & 11,83 & 11,83 & 0,00 & 11,83 \\
Total, million USSD & 2,446 & 688 & 3,134 & 2,683 & 297 \\
\hline
\end{tabular}




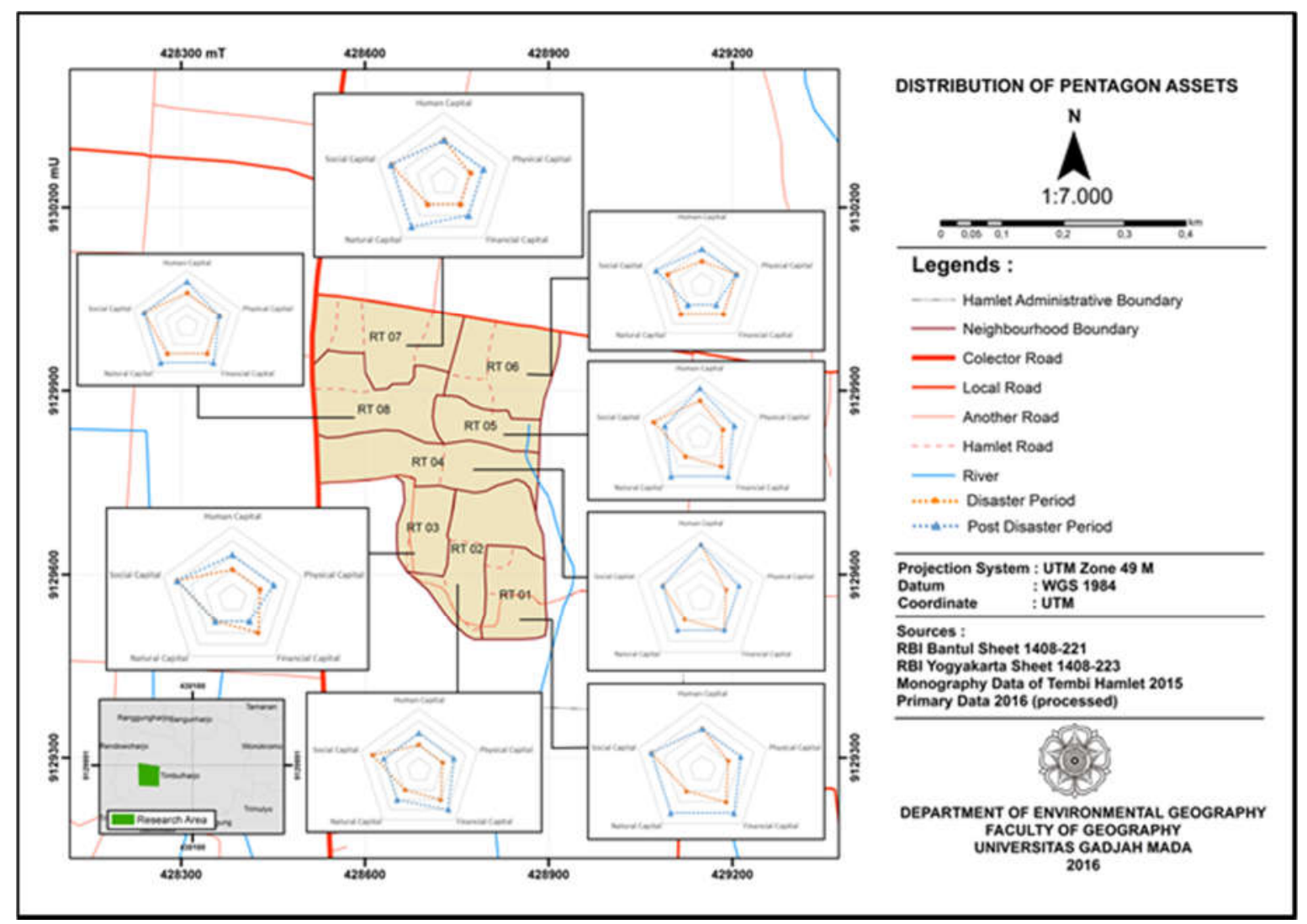

Figure 7. Pentagon Asset at Tembi Sub-District, Yogyakarta

especially before disaster. The limitation of natural assets was mainly due to limited activities in the sector of agriculture and husbandry limited only as side income. Most the household in each neighboring block practiced to conduct small husbandries at their backyards, and managed small piece of land for gardening, yet produce in large scale of natural resource production. Again, this was not their main source of living. They have had more interest to conduct services in traditional hand-made souvenirs, involve in artworks galleries, and other related touristic activities, such as working as hand-made souvenirs in several workshops, renting rooms for tourists and etc.

Some part of the neighboring blocks claimed to experience low human and financial asset before disaster occurrence. This is the fundamental reasoning for no-fasttrack record towards the improvement of their micro-smallmedium enterprises. The condition remained stagnant until the arrival of key stakeholder concerns towards micro-smallmedium enterprises development for the area. The key stakeholder had played a very pivotal role in changing general paradigm of local business owner to embrace wider market target. Hence, local product such as handicraft, paintings, and other art objects were introduced to international market, including tourism business, which had increased their side-income into a promising business. As the business arises, hence, earthquake strike, which put their most promising livelihood shattered into pieces. Again, we learned that source of funding to support micro-smallmedium enterprises at Tembi was mainly originated from external capacities.

Moving to the pentagram pattern after disaster occurrence, it reflected a very significant improvement, along with financial assets in the whole area and physical assets in some part of the area. Despite the wreaking havoc, as for some neighboring blocks (RT 06 and RT 08), claimed that the physical assets were stagnant even at the aftermath of disaster occurrence. The research revealed that as asset ownership in the area was not impacted severely due to the earthquake, hence there was not much assistance provided to increase the physical assets. Meanwhile, the rest of the neighboring blocks received dynamic change upon physical assets. Due to the fact their assets such as housing, vehicle, productive land, productive sector, and some infrastructures were impacted severely by the earthquake hence it received tremendous attention from external parties. The dynamic change towards physical assets triggered by aid stimulation from government, non-government and other organization. Damaged house receives recovery and reconstruction fund from the government (IDR 15.000.000 per household), some other assistance delivered in construction material, some other nongovernment organization (ReKompak) provided them with constructor assistance to build earthquake resistant building. Social asset in study area did not change. In line this social asset does not only stop at recovery in post disaster period, but also continuous at the recovery stage. They work together to decide on capacity building programs of affected people, so that they can survive and restore their livelihoods to pre disaster even increased. To summarize, social asset tremendous in the research area due to internal capacity, while physical and financial asset were abundant due to external capacities. The following Figure 10 indicated feature of pentagram likelihood in the research area. 


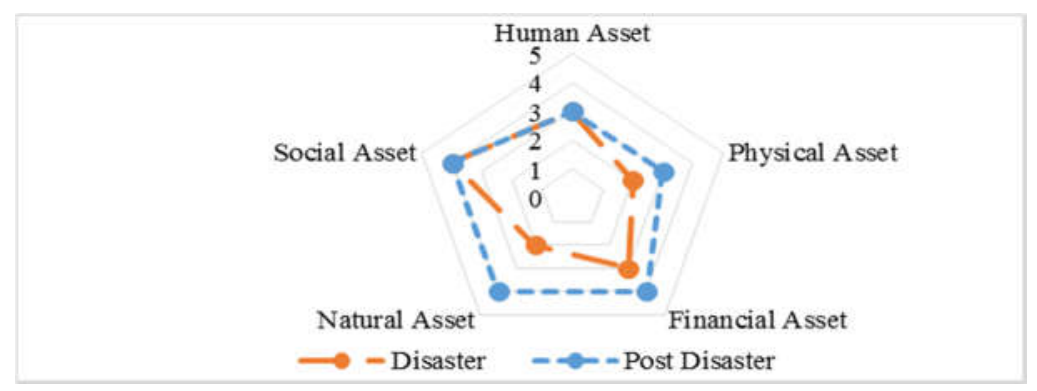

Figure 10. Livelihood Pentagram Asset at Research Area before disaster (orange), also post disaster (blue), (Analyze Result, 2016)

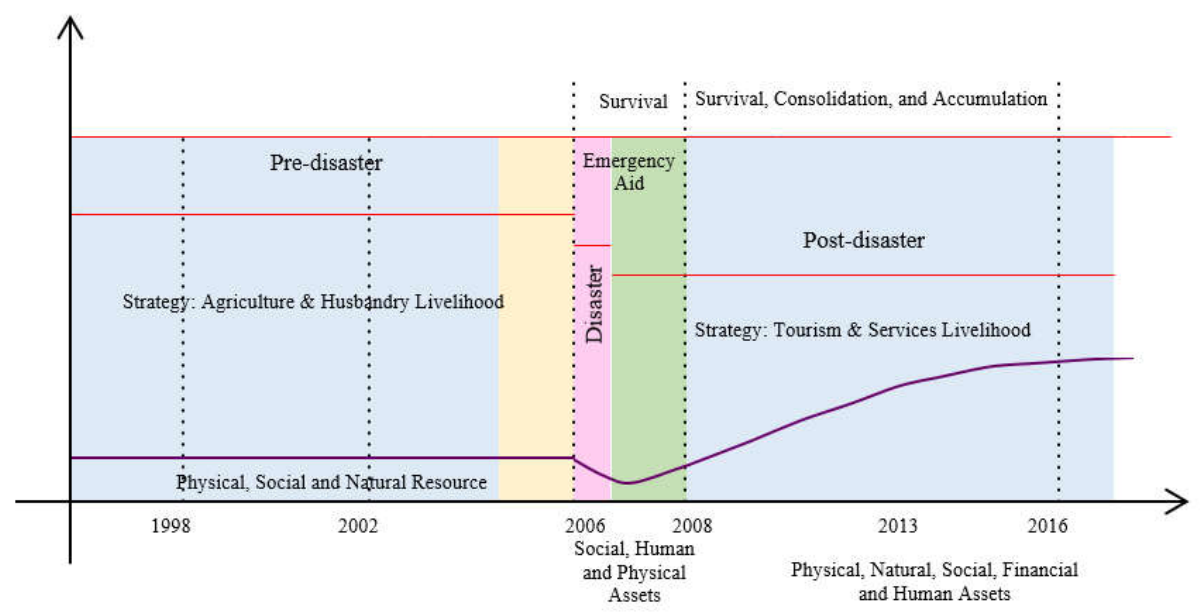

Figure 9. Livelihood strategy histogram in Tembi, Bantul, Indonesia (Analyze Result, 2016)

The research highlights several ancillary data to support and to validate the findings. Initially, local GDP was increasing from 2011 - 2016, which means, at the aftermath of disaster 2006, there are significant trend strengthening local economic growth. Indeed, there are several top-listed sectors contribute most to local growth, such as electricity and gas, information and communication, retails, tourism and services also others activities. Derived from the data, local performance supports regional economic achievement. Concomitant to the ancillary data, Tembi was and still an example of area developed and resilient towards disaster due to strong tourism and services sectors.

In general, the local change has been greatly influenced by tourism and cultural activities. The preliminary finding indicated that there are two exit strategies conducted to attain resilience, such as "no-plan scenario", and "changeplan scenarios". No-plan scenario refers to no shifting livelihood necessary taken at the aftermath of disaster, while change-plan scenarios refers to implementation of new livelihood mechanism at the aftermath of disaster. Predominantly, community experienced no-plan scenarios since their tangible assets and intangible resource to support their livelihood was already adequate (Farrington, Ramasut, \& Walker, 2002). Other argued available assets they had were abundant, therefore, it supports their ability to cope, and recover from shocks (Scoones, 2009). The remaining questions, then, what are the abundant assets supporting them to opt no-plan scenarios?

The following Figure 9 depicts histogram of resilient process in the research area. The histogram consists of three phases, pre disaster phase (before 2006), per disaster phase
(May - December, 2006), and post disaster (2007 onwards). There are three mechanism conducted accordingly. From indepth interview data, during pre-disaster phase, local livelihood strategy mainly focused on diverse sectors, while agriculture and husbandry as side income to the family which strengthen local capacity. During per disaster, their source of living fully dependent upon emergency aid and humanitarian assistance. At the aftermath of disaster, their strategy mostly dealt with tourism and services. Highly interest of the community to conduct tertiary economic activities is due to the economic advantage (economic motive). Existence of the opportunity to earn a larger income was increasingly attracting the community to conduct tertiary economic activities.

Derived from this histogram, the resilient towards disaster in research area are actually conforms of survival strategies during emergency situation. The emergency situation shattered most of the micro-small-medium enterprises; therefore, their survival mechanism was depending upon humanitarian aids. During consolidation, they predominantly opted "no-change scenarios" by keeping their previous job to earn living but expanding their activities, which relates to tourism and services. As for the long run, they had accumulation of asset to improve their ability. Some of them even decided to "change scenarios", by escalating their scale of business with additional financial investment and expanding their market. To do so, they had initiated collective social capital. Using such institution support, thus, any householdbased activities were able to access financial support to expand their ability to earn living out of it. 
Enabling Environment Towards Disaster Resilient

This research understood there are two types of embedded local assets in the research area. First, dynamic tangible assets such as physical, natural and financial assets, which notably coexisted in the research area, however its availability yet stable. Second, stagnant intangible assets such as human and social assets, which off-course tremendously exists in the research area through time. In the rural context, the social and natural assets are generally excessive, while in urban context, the human, financial and physical assets are abundant. Partaking to the idea, peri-urban area characterized by combination of both whereas social assets are still dominant, while human assets are quite promising. There were involvements from other parties in collecting physical, natural and financial assets for the research area, i.e. government incentives, non-government assistance, and many other community involvements to improve local capacity to increase their resilience.

The research area experienced a very strong social asset. The local term was "gotong royong". Such term existed and rooted in traditional Javanese culture since the earlier era of Mataram Kingdom (750 AD). They believed that their main task as human being is twofold, first to serve the God, and second to serve fellow human. Therefore, in Javanese culture, family was not bonded only with genetic and blood relation, but also neighbors considerably as main family circle. Any occasion exposed to particular household, such as celebrating newly born baby, wedding, death service, house warming, house building, even into regular social meeting, economic activities and religious activities are borne together by the community in the neighboring blocks (Figure 11). This bond can be used as a social capital that can be used to help members of the community to achieve common goals, as in the case of disaster management because it is user-friendly (Kusumasari \& Alam, 2012).

Their effort was enormous, the community genuinely worked together to rehabilitate and rebuild the damaged houses in the area. Furthermore, many non-government organizations provided assistance to rebuild earthquake resistance construction and create evacuation route for the areas as argued earlier. In addition, "gotong-royong" also nurture high level of trust, solidarity, and it is developed within the structural and non-structural community system (Hizbaron, et al., 2014).

Correlate the idea, community in general opted no-plan scenarios at the aftermath of disaster. They did not change their main source of income and greatly escaped from the crisis due to abundant intangible assets. Meanwhile, microsmall-medium enterprises group in general opted changeplan scenarios at the aftermath of disaster. $91,67 \%$ out of total 84 microeconomic micro-small-medium enterprises opted change-plan scenario at the aftermath of disaster, shifted their livelihood from agriculture based to tourism and service-based activities.

Henceforth, as cited from Carney, 2003 and Farrington, Ramasut, \& Walker, 2002), the research argues that livelihood strategies at Tembi were collectively driven by people centered, participative, responsive and multi-level partnership. The main idea of sustainable livelihood in the area was not mainly to minimize poverty as argued by Baiquni, 2007 and Rijanta, et al., 2014. Herewith, resilience in the research area characterized as a condition that able to cope or recover from stress, and maintain their existing capacities despites its uncertainty. This argument is in line to the idea from Chambers \& Conway (1991), Ellis (1999) and Plummer \& Armitage (2007), that also consider resilient livelihood as a component of coping, recovering, maintaining capacities and ensuring future states (Chambers \& Conway, 1991; Ellis, 1999; Plummer \& Armitage, 2007). How can we define its resilience without questioning whether their current livelihood is feasible for long run? Cited from Baiquni (2007) and Hizbaron, et al (2014), as long as its restraint community from any collapse condition and put them in a stable or even regenerate, hence we may assume that their current state is resilient. Or, as long as the current livelihood support local dweller to access basic infrastructure, thus their current state also resilient (Rose \& Krausmann, 2013). To date, the research highlights that local dweller experienced abundant access towards economic opportunities as well as humanitarian access despite its marginal location at peri-urban areas.

Evidently, local resilience in Tembi District had been pulled together by existence of micro-small-medium enterprises. The preliminary argument that urban area consists of heterogeneous livelihood or jobs are credibly correct, however, the existing variety needs to be supported with extended activities collectively as well as equal access to it. This extended collective activity generates more income, which at the end support local resilience even more. In short, the existing access, asset and activities in the research area has created an enabling environment to tackle disaster.

\section{Re-thinking Evaluation Scan of Sustainable Livelihood in Disaster Risk Management}

Unexpectedly, an area exposed to shock need to conduct quick scan to the resilient of the area. Is histogram and pentagram adequate to evaluate existing resilient at Tembi area? The research then tries to reformulate thinking to evaluate how external capacity contribute to create resilient in the area.

Theoretically, in order to evaluate sustainable livelihood at peri-urban risk area, hence there are stages to scan the initial condition refers to primary data and analyze result (Table 5). There are several indicators to scan, such as shock/stress, impact, assets, vulnerability, policy, institution, interaction, multi sectors. Relevant to the finding that Tembi area was also supported by abundant external capacities, thus, the research evaluates policy, institution, interaction and multi sector to represent the observation.

The local resilient expects more "plus" exist at the post disaster phase. Herewith, the evaluation scan indicated that policy, institution, interaction and multi sector are increasingly getting more intensive at the aftermath of disaster. Concomitant to the finding, the research learned that vulnerability dynamic through times, however, the research revealed that policy incorporated non routine policy during and after disaster. In line with this condition, Dusun Tembi designed as tourism area according to Regional Spatial Plan Year 2010 - 2030 (RTRW 2010-2030). It is predicted to grow rapidly, while social and economic development were impaired due to potential of hazards (Bappeda of Bantul Regency, 2007; Hizbaron, et al, 2012; Wimbarda, et al, 2014). The existence of local institution was strengthened through times, together with involvement of interaction from multi sectors. In terms of policy, Indonesian national and regional governments had mainstreamed disaster risk reduction, which involved many stakeholders, i.e.: 
Table 5. Evaluation scan towards Sustainable Livelihood within Disaster Risk Management in Tembi, Yogyakarta

\begin{tabular}{|c|c|c|c|}
\hline $\begin{array}{c}\text { Sustainable Livelihood } \\
\text { Approach }\end{array}$ & Pre Disaster & Per Disaster & Post Disaster \\
\hline Shock/Stress & ++ & +++ & ++ \\
\hline Impact & -- & +++ & + \\
\hline \multirow[t]{3}{*}{ Assets } & $++($ Social $)$ & $+++($ Social $)$ & $+++($ Social $)$ \\
\hline & $++($ Physical $)$ & $++($ Human $)$ & $+++($ Human $)$ \\
\hline & $++($ Natural $)$ & $+($ Physical $)$ & $+++($ Financial $)$ \\
\hline Vulnerability & ++ & +++ & ++ \\
\hline Policy & $+($ Routine $)$ & $++($ Non Routine $)$ & ++ (Routine) \\
\hline Institution & -- & + & ++ \\
\hline Interaction & + & ++ & +++ \\
\hline Multi sector & + & ++ & +++ \\
\hline Resilience & - & - & + \\
\hline Livelihood Strategy & Agriculture \& Husbandry & - & Tourism \& Services \\
\hline Mechanism Strategy & Daily Routine & Survival & Consolidation \& Accumulation \\
\hline
\end{tabular}

Source: Analyze Result, 2016

1. Act. No. 24/2007 on Disaster Management,

2. Act. No. $26 / 2007$ on Spatial Plan,

3. Act. No. $6 / 2014$ on Village,

4. Presidential Decree No. 8/2008 on National Disaster Management Agency,

5. Ministry of Home Affairs Regulation No. 46/2008 on Organization and Working Procedure of National Disaster Management Agency,

6. Government Regulation No. 21/2008 on Operational Guideline of Disaster Management,

7. Government Regulation No. 22/2008 on Funding and Humanitarian Aid Management for Disaster,

8. Government Regulation No. 23/2008 on Community Participation in Disaster Management,

9. Governoor Regulation Daerah Istimewa Yogyakarta No. 8/2010 on Disaster Management,

10. Governoor Regulation Daerah Istimewa Yogyakarta No. 10/2010 on Taskforce of Local Disaster Management Agency,

11. Governoor Regulation Daerah Istimewa Yogyakarta No. 55/2010 on Standard Operational Procedure on Disaster Management.

12. Bantul District Government Regulation No. 4 Year 2011 on Spatial Plan of Bantul District

In more details, there were 19 regulations generated by Republic of Indonesia National Disaster Management Agency (Badan Nasional Penanggulangan Bencana) during period 2007-2010, and 57 regulations generated during period 2010-2015. These abundant regulations had been implemented in various local disaster management agencies, including Yogyakarta. However, in the case of Yogyakarta, such tremendous policy and institutional support does a very unique contribution towards local ability to survive using their very own resources.

Critically, the evaluation scan is essential to complete the previous observations towards pentagram asset identification. In order to identify any changing livelihood, one must not only seek possibility from natural, physical, human, social and financial asset per se. Scholar must also consider the possibility of political assets to support such evaluation. In this case the evaluation scan includes, policy, institution and interaction among sectors to evaluate whether any of those indicators plays important role during the process of sustaining livelihood strategies. Herewith, coincidently, the research area indicates that the political assets are abundant, and this for sure supports urban dwellers' spirit to be resilience towards disaster despite using their very own resources.

\section{CONCLUSION}

How urban livelihood survived from disaster? This research has conducted several methods to strengthen findings. First, the research conducted general observation to local access, asset, and activities to depict general livelihood. Second, partaking to the idea of spatial temporal approach, the research highlights assets distribution through different neighboring block through times. This was intended to provide detailed yet comprehensive overview towards the area. The research employed multi-level unit analysis, starting from individual/household level to own micro-small-medium scale enterprises. Third, the research collects ancillary data to support the finding and gather validated information from many stakeholders. Fourth, the research rethinking the finding through a scanning mechanism to analyze resilience.

The result revealed that 1) the micro-small-medium enterprises in urban area is resilient towards earthquake disaster due to fair physical, natural and financial assets management and abundant social, human and institutional assets. After a decade, these physical, natural, financial, social, human and politic assets have created enabling environment towards behavioral change of local society; 2) Despite various livelihood strategies existed in urban areas, the research highlighted three types of livelihood strategies within disaster 
risk management perspective, i.e. survival (per disaster), consolidation by no-change plan mechanism and accumulation strategies by change plan mechanism (post disaster). The research also revealed that the framework of sustainable urban livelihood is able to explain modified asset management within disaster risk management context. The pentagram is able to portray existing assets specifically in each spatial unit. Critically, pentagram assessment is able to identify feasible local assets and activities, however it left the politic aspect from the spotlight. Meanwhile, the histogram is essential to describe temporal management within disaster phase. According the histogram, the research area revived from disaster occurrence using three types of livelihood strategies i.e. survival (per disaster), consolidation by nochange plan mechanism and accumulation strategies by change plan mechanism (post disaster). Indeed, urban area consists of heterogeneous livelihood or jobs; however, the existing variety needs to be supported with extended activities collectively in order to attain resilience. In the future, the local government should re-think on how to conduct quick scan to an area with huge disaster occurrence, in order to evaluate resilient.

\section{ACKNOWLEDGEMENT}

Author would like to express theri gratitude to the Government of Tembi Hamlet, Sewon Sub-District, Bantul District and all of local stakeholders

\section{REFERENCE}

Allison, E. H., \& Ellis, F. (2001). The livelihood approach and management of small-scale fisheries. Marine Policy, 25, 377 -388 .

Aven, T. 2011. On Some Recent Definitions and Analysis Frameworks For Risk, Vulnerability, And Resilience. Risk Analysis 31(4): 515-522.

Baiquni, M. (2007). Strategi Penghidupan Di Masa Krisis. Yogyakarta: IdeAs Media Yogyakarta

Birkmann, J. (2006). Measuring Vulnerability to Natural Hazards: Towards Disaster Resilient Societies. Tokyo: United Nations University Press.

BPS Bantul. (2016). Kabupaten Bantul dalam Angka 2008 (Statistics of Bantul District). Bantul: Badan Pusat Statistik Kabupaten Bantul.

Cardona, O. D. (2003). The Need for Rethinking the Concepts of Vulnerability and Risk from a Holistic Perspective: A Necessary Review and Criticism for Effective Risk Management. In G. Bankoff, G. Frerks, \& D. Hilhorst, Mapping Vulnerability: Disasters, Development and People. London: Earthscan Publisher.

Carney, D. (2003). Sustainable Livelihood Approaches: Progress and Possibilities for Change. Department for International Development. Toronto: DFID.

Chambers, R., \& Conway, G. R. 1991. Sustainable Rural Livelihoods: Practical Concepts for the 21st Century. International Development Studies. IDS Discussion Paper 296.

Coaffee, J. (2008). Risk, resilience and environmentally sustainable cities. Energy Policy, 36, 4633-4638.

Cutter, S. L. (1996). Vulnerability to Environmental Hazards. Progress in Human Geography, 529 - 539.

Cutter, S. L., Barnes, L., Berry, M., Burton, C., Evans, E., Tate, E., et al. 2008. A place-based model for understanding community resilience to natural disaster. Global Environmental Change $18,598-606$.

Cutter, S. L. (2003). The Vulnerability of Science and the Science of Vulnerability. Annals of the Association of American Geographer, 1 - 12.

Cutter, S. L., Burton, C. G., \& Emrich, C. T. 2010. Disaster
Resilience Indicator for Benchamarking Baseline Condition. Journal of Homeland Security Emergency Management , 7 (1), $1-22$.

DFID. (1999). Sustainable Livelihood Guidance Sheets. London: International Development

DFID. (2001). Sustainable livelihoods Guidance Sheets 2.

http://www.eldis.org/vfile/upload/1/document/0901/section2.pdf. Accessed on 24 February 2016 time 23.10 WIB

Disdukcapil Bantul. (2010). Data Kependudukan Triwulan 12010. Bantul: Disdukcapil Bantul (http:// disdukcapil.bantulkab.go.id/).

JRF. (2007). One Year After The Java Earthquake and Tsunami: Reconstruction Achievements and the Result of the Java Reconstruction Fund. Jogjakarta Reconstruction Fund.

Farrington, J., Ramasut, T., \& Walker, J. (2002). Sustainable Livelihoods Approaches in Urban Areas: General Lessons, with Illustration from Indian Cases. Working Paper, 162.

Ellis, F. (1999). Rural Livelihood Diversity in Developing Countries: Evidence and Policy Implications. Overseas Development Institute. Natural Resource Perspective.

Elnashai, A. S., Kim, S. J., Yun, G. J., \& Sidarta, D. (2007). The Yogyakarta Earthquake of May 27, 2006 - MAE Center Report No 07 - 02. Illinois: Mid-America Earthquake Center University of Illinois at Urbana-Champaign.

Fekete, A., Hufschimdt, G., Kruse, S., 2004. Benefit and Challenges of Resilience and Vulnerability for Disaster Management. Int. J Disaster Risk Sci 5 : 3-20

Hadi, S. (2008). Improving vulnerable urban space in post-disaster in Yogyakarta and Central Java, Indonesia: Participatory and Comprehensive Approach. In T. Kidokoro, J. Okata, S. Matsumura, \& N. Shima, Vulnerable Cities: Realities, Innovations and Strategies (pp. 225 - 240). Tokyo: Springer Publisher.

Hizbaron, D. R., Iffani, M., Wijayanti, H., \& Wicaksono, G. N. (2016). Disaster Management Practices Towards Diverse Vulnerable Groups in Yogyakarta. Advance in Social Science, Education and Humanities Research, 79, 7-12.

Hizbaron, D. R., \& Hadmoko, D. S. (2016). Mapping Vulnerability For Kelud Volcano, Indonesia - Approach Towards Disaster Resilience. 6th International Conference on Building Resilience: Building Resilience to Address the Unexpected (hal. 52). Auckland: Massey University of New Zealand \& University of Auckland New Zealand

Hizbaron, D. R., Sudibyakto, Jati, R., Kanegae, H., \& Toyoda, Y. (2015). A Participatory Evacuation Map Making Towards Sustainable Urban Heritage Kotagede, Yogyakarta. Forum Geografi, 29 (1), 11-22

Hizbaron, D. R., Rahmat, P. N., Seyaningrum, A., \& Malawani, M. N. (2015). Kajian Pola Spasial Kerentanan Sosial, Ekonomi, dan Fisik di Wilayah Rawan Erupsi Gunungapi Merapi, Yogyakarta. Jurnal Riset Kebencanaan Indonesia , 1 (1), 1624.

Hizbaron, D. R., Mei, E. T., Retnowaty, A., Tyas, D. W., \& Marfai, M. A. (2016). Vulnerability of Volcanic Ternate Island: Towards Ecosystem Based Disaster Risk Management. The 7th Indonesia Japan Joint Scientific Symposium IJJSS. Chiba, Japan: IJJSS.

Hizbaron, D., Hadmoko, D., E.T.W Mei, S. M., Laksani, M., Tiyansyah, A., Siswanti, E., \& Tampubolon, I. (2018, June 22). Towards measurable resilience: Mapping the vulnerability of at-risk community at Kelud Volcano, Indonesia. Applied Geography, 97, 212-227.

Hizbaron, D., Baiquini, M., Sartohadi, J., \& Rijanta, R. (2012, August 30). Urban Vulnerability in Bantul District, Indonesia Towards Safer and Sustainable Development. Sustainability, 4 (doi: 10.3390/su4092022), 2022-2037.

Indonesian Government Law No. 20 of 2008 on Micro, Small and Medium Enterprise.

Kusumasari, B., Alam, Q., \& Siddiqui, K. (2010). Resource Capability 
for Local Government in Managing Disaster. Disaster Prevention and Management: An International Journal , 19 (4), 438-451.

Mileti, D. (1999). Disaster by Design. In N. R. Britton (Ed.), The Changing Risk Landscape: Implications for Insurance Risk Management. AON Group Australia.

Nakagawa, Y., \& Shaw, R., 2004. Social Capital : A Missing Link to Disaster Recovery. International Journal of Mass Emergencies and Disasters, Vol. 22, No 1, pp 5-34

Pelling, M. (2003). Paradigms of Risk. In M. Pelling, Natural Disaster and Development in a Globalizing World (pp. 3 17). London: Routledge PublisherPemerintah Kabupaten Bantul. 2014. Data Monografi Dusun Tembi 2014. Padukuhan Tembi : Kabupaten Bantul

Plummer, R., \& Armitage, D. (2007). A resilience-based framework for evaluating adaptive co-management: Linking ecology, economics and society in complex world. Ecological Economics, 61, 62-74.

Rijanta, R., Hizbaron, D. R., \& Baiquni, M. (2014). Modal Sosial dan Manajemen Bencana. Yogyakarta, Indonesia: Gadjah Mada University Press.

Rose, A., \& Krausmann, E. (2013). An Economic framework for the development of a resilience index for business recovery. International Journal of Disaster Risk Reduction (5), 73-83.

Theo, Donum. 2016. UKM dan Pariwisata Jogja. https://gudeg.net/ $\mathrm{read} / 4072 / \mathrm{ukm}$-dan-pariwisata-jogja.html . accessed on 20 April 2016 time 22.56 WIB

Thywissen, K. (2006). Component of Risk: A Comparative Glossary. Bonn, Germany: SOURCE No 2 (Studies of the University: Research, Council, Education).

UNDP. (2004). A Global Report: Reducing Disaster Risk A Challenge for Development. New York: UNDP.

UN/ISDR. 2004. Living with Risk : A Global Review of Disaster Reduction Initiatives Volume II Annexes. Switzerland : United Nations. ISBN : 92-1-10106509

Shaw, R., Gupta, M., and Sharma, A. 2003. "Community recovery and its sustainability: lessons from Gujarat earthquake of India." Australian Journal of Emergency Management 18 (2): 28-34.

Scoones, I. (1997). Sustainable Rural Livelihoods A Framework for Analysis. Institute of Development Studies. IDS Working Paper 72.

Scoones, I. (2009). Livelihood perspective and rural development. Journal of Peasant Studies, 36 (1).

Wimbarda, R., Sagala, S.A., Pratama, A.A., dan Wijayanti, A.R. 2014. Integrasi Rehabilitasi Sosio-Ekonomi Penduduk Setelah Gunung Merapi Tahun 2010 terhadap Perencanaan Pemulihan. Resilience Development Initiative April 2014. ISSN : 2406-7865 
